\title{
URBAN GREEN INDICATORS: A TOOL TO ESTIMATE THE SUSTAINABILITY OF OUR CITIES
}

\author{
C.M. TUDORIE ${ }^{1}$, E. GIELEN ${ }^{2}$, M. VALLÉS-PLANELLS ${ }^{3} \&$ F. GALIANA ${ }^{3}$ \\ ${ }^{1}$ Universitat Politècnica de València (UPV) Spain. \\ ${ }^{2}$ School of Civil Engineering. Department of Urbanism. Universitat Politècnica de València, Spain. \\ ${ }^{3}$ School of Agricultural Engineering and Environment. Department of Rural and Agrifood Engineering. \\ Universitat Politècnica de València, Spain.
}

\begin{abstract}
In Europe, more than $70 \%$ of the population lives in an urban area. All the challenges related to land use conflicts, demographic changes, climate resilience and human well-being are concentrated inside the cities, since the population is already living in urban areas, which are more and more compact and dependent on grey infrastructure. In this context, urban green infrastructure represents a sustainable solution to maintain the benefits and services provided by urban ecosystems and an efficient urban planning tool to face the urban challenges.

The sustainability of our cities can be reached adopting an innovative vision using the concept of ecosystem services of the urban green infrastructure. Different initiatives to assess the benefits provided by green infrastructure have emerged in the last decade. However, very few take into account the whole range of services provided by urban green infrastructure.

The present article provides a systematic search and synthesis of the most important literature to review indicators of urban green infrastructure. The main goal is to give an insight of how urban green infrastructure is measured in practice. Results show the set of ecosystem services that are being considered when assessing sustainability of green infrastructure and identify the most recurrent indicators at the different scales. This work is expected to contribute to the improvement of the evaluation of green infrastructure effectiveness for providing benefits for urban dwellers.

Keywords: ecosystem services, green space indicators, sustainability, urban challenges, urban green infrastructure.
\end{abstract}

\section{INTRODUCTION}

Concepts like sustainability and resilience are the main challenges of the city's cores characterized by continue densification, where daily enjoyment of green urban space is becoming a privilege. Sustainability tries to align social science, environmental preoccupation, civic engineering and future technology. According to United States Environmental Protection Agency [1] sustainability refers to the mechanisms of natural systems, its diversity and capacity of producing everything, which is essential for the ecology balance. It also acknowledges the overexploitation of natural resources by inhabitants in order to achieve a modern lifestyle. Sustainable development includes terms of three pillars, environment, economy and society [2].

On one hand, sustainability is important for the cities to reach the 17 sustainable goals established by United Nations Commission [3]. On the other hand, different conferences, reports, global movements and initiatives concerning the future health of our planet testify to the importance of city sustainability. For instance, Habitat III [4] aimed to warn the society about the harmful and negative economic growth and globalization consequences on the environment and natural resources; Green Economy Initiative (GEI) is a global movement whose purpose is to promote "green governments' economies and to reduce the threats caused by ecological crisis. United Nations Development Programme (UNDP) is fully supporting the implementation of New Urban Agenda by launching Sustainable Urbanization Strategy 
[5], through which cities could become sustainable solutions for conflicts, demographic and environmental challenges [1]. Biodiversity loss and ecosystem degradation represent the main cause of the urgency of sustainable solutions and within the sustainable development, green infrastructure (GI) occupied its own niche.

GI is an alternative Nature Based Solution (NBS) to grey infrastructure for the alarming problems faced by cities and citizens and its goal is to achieve the improvement of urban development [6]. According to European Commission [7], GI is strategically planned network of natural and semi-natural areas with other environmental features designed and managed to deliver a wide range of ecosystem services (ES) such as water purification, air quality, space for recreation and climate mitigation and adaptation. When this new concept appeared, as derived from landscape ecology, it included only the natural and semi-natural networks [8], but currently, green infrastructure focal point has moved to cities and became the backbone of urban green infrastructure. Urban GI (UGI) provides environmental, economic and social benefits. Due to its multi-functionality, UGI could be proposed as useful urban design tool and landscape management process integrating many different disciplines and concepts [9].

In addition, UGI represents an important agent against climate change. Greenery is promoted for its potential cooling effect of trees and green spaces. According to Benedict et al. [10], the function of green infrastructure is to be a supporting conservation goals tool, to outline the ecological function and its role as a connective ecological element. Besides cultural function, green arteries facilitate habitat for urban fauna and flora, providing in the same time air regulation and seed dispersal.

UGI is a big supporter of sustainable and healthy lifestyles, urban livability and wellbeing [11]. GI should be seen as a facilitator of increased mobility, health and education, economical stimulator, involving leisure and social facilities for different stakeholders.

Nowadays, there is an increasing concern of the relevance of providing evidences of benefits, delivered by green infrastructure, in order to prove that an increase of urban green spaces would provide a proportionally larger number of ecological, economic and social benefits and services. For this purpose, indicators that allow the assessment of the performance of green infrastructure are needed [14]. The main goal of this work is to analyze how urban green infrastructure benefits are practically measured.

The objectives of this article are to identify the ES considered in literature to measure the benefits provided by the UGI; to point out integrated indicators used in literature for the assessment of ES; to discover if GI could be a beneficial territorial planning tool and finally to find out if environmental indicators measure only the environmental benefits or there is any interdependence between the social, economic and ecological aspects.

\section{METHODOLOGY}

First, we look for UGI indicators in the literature that were applied to indicate the effectiveness of ES generated by green spaces. The urban green infrastructure indicators constitute a collection of data from existing databases, which could be simple recommendations of sustainable indicators made by researchers, agencies, organizations or data collection from cities, looking for the case studies with promising results, after using the indicators to test different theories at city scale.

An extensive literature review of the topic, urban green infrastructure indicators, was carried out by using systematically different search engines like Scopus, Web of Science, Google Scholar and electronic libraries connected to UPV. 
To help finding reliable references for the research, the identification of keywords was necessary. The set of keywords identified that helped on research topic proposed are: ecosystem services; green space indicators; sustainability; urban challenges; urban green infrastructure.

The searching process was limited to studies published during a fixed period (2000-2018) and only the academic articles and grey informs were chosen. There has been a significant increase of published literature on this topic in the last 3 years.

Second, indicators have been classified according to Common International Classification of Ecosystem Services (CICES) [12] created by European Environment Agency (EEA) [13]. CICES Classification is divided into three themes: Provisioning, Regulation and Maintenance and Cultural, each of them having nested service classes, groups and types (Table 1). Some indicators could not be included in any of the classes. That is why other inspiring sources were necessary to classify the indicators that could evaluate cultural services [9], [14]. Valles-Planells et al. [9] proposed a new classification of landscape services and their related concepts and also added new services. In this article, from this second classification, were chosen three classes (mental health, physical health-associated with active enjoyment and recreation- and social fulfillment grouped with social interactions), in order to range the ambiguous indicators, left without an exact framing. EKLIPSE [14] was the last reference, which helped to range other two classes of cultural indicators, participatory planning and governance (seen as challenge number 7) and accessibility, availability and proximity (seen as challenge 4: green space management). Even some researchers [14-16] proposed a hypothetical cultural class, formed by economic services, almost all indicators which measure the monetary value of economic services, were decided to be attached to provisioning services. They represent a real and quantified benefit, e.g. value of avoided grey infrastructure design (construction and management cost, increase in property values [16] and potential for economic opportunities and green jobs [14]). A new service group, related with water quality called regulation of drought was attached to the

Table 1: Structure of CICES classification [12] (number of classes and groups) and definition of Ecosystem services theme.

Ecosystem services
Provisioning
\begin{tabular}{|c|c|}
\hline N. Classes & Groups \\
\hline 3 & 8 \\
\hline
\end{tabular}

Regulation and maintenance

\begin{tabular}{|c|c|}
\hline N. Classes & Groups \\
\hline 4 & 11 \\
\hline
\end{tabular}

Cultural

\begin{tabular}{|c|c|}
\hline N. Classes & Groups \\
\hline 2 & 4 \\
\hline
\end{tabular}

Definition

'All nutritional, non-nutritional material and energetic outputs from living systems as well as abiotic outputs (including water)'. It is make the difference between biotic and abiotic outputs.

The division level covers the transformation of biochemical or physical inputs in form of wastes, toxic substances and other nuisances and the regulation of physical, chemical, biological conditions, which are benefits, less tangibles than goods but important for human beings. Includes 'non-material and non-consumptive outputs of ecosystems (biotic and abiotic), that affect physical and mental states of people'. 
new classification of ES in order, to classify the indicators proposed by Schyns et al. [17], e.g. agricultural drought indicators, agricultural suitability under rain-fed condition, aridity indicators.

After the reclassification, service classes count 18 , instead of 9 , the initial number of service classes proposed by CICES [12].

In the following, the proposed urban green infrastructure indicators will be analyzed. First, it has been presented a table with a new combination of ecosystem services ranged gathering the two existent classifications mentioned before and new classes and groups inspired from different references. Indicators are classified in function of ecosystem services diversity regarding nested categories and subcategories. Then, the repeated indicators found in the literature will be described in different tables and figures, which indicators use quantitative and qualitative data and their proportion in the proposed classification and finally, examples of integrated indexes will be mentioned.

\section{RESULTS AND DISCUSSION}

From all the studies found, UGI indicators were subject of 21 references [13-32]. They include qualitative and quantitative measurements of all the categories of ES and contain 175 ecosystem service indicators, able to measure the benefits provided by UGI. Generally, the idea of green indicators is seen as a possible solution to quantify urban challenges or a hypothetical urbanism planning tool. Therefore, the majority of references are making proposals, without having real results of measured benefits provided by urban green infrastructure, e.g. EKLIPSE [14], Pakzad and Osmond [16], Valles et al. [9], EPA [1], Artmann et al. [31] and McKinsey et al. [33]. Nevertheless, there are also articles, which report their results, e.g. Refs. [13], [16], [19-21], [26], [27], [31], [32].

UGI indicators have been ranged using two existing classifications [9], [12], where some new classes and groups have been added (Table 2). The first column of Table 2 contains all three main categories of ecosystem services (marked with letters from A to C). The second level, class service is numbered with Arabic numerals and the last one, which represents service group, is not marked or numbered. The second column reveals the number of indicators found for each class or group and, in the last one, author's name is indicated.

From the total number of indicators, 24 indicators $(13.71 \%)$ could assess the effectiveness of provisioning services, 83 indicators $(38.86 \%)$ are used to measure regulating and maintenance services and $68(47.43 \%)$ indicators could estimate cultural services (Fig. 1). The most repeated indicators are shown in Table 3.

From 175 indicators, 20 indicators considered for all three categories of ES have been repeated several times. For instance, carbon storage, carbon sequestration, biodiversity, structural connectivity, total green area or proximity to green spaces, have been mentioned or applied several times in literature [15], [18-24], [25], [27], [32]. With regard to regulation and maintenance services, the most repeated indicators $(14.46 \%)$ are related to atmospheric regulation, water quality, diversity and functional connectivity. Within cultural services, the most frequent indicators are connected to accessibility, availability, proximity of green spaces. Finally, only one indicator is repeated within the group of provisioning services, which is related to monetary value of properties.

Concerning the data type (Fig. 2), the percentage of quantitative indicators to estimate the benefits of provisioning (11.43\%) and regulation and maintenance services (40\%) are higher than qualitative indicators percentage $(2.29 \%$ and $7.43 \%)$. When it comes to cultural indicators, qualitative data dominates $(21.14 \%)$. 
Table 2: Urban Ecosystem services (UES) and number of associated indicators (NAI) based on CICES [12], Valles-Planells [9] and EKLIPSE [14].

Urban ecosystem services

NAI References

PROVISIONING

\section{A.1. Nutrition}

A.1.1 Terrestrial plan and animal foodstuffs

A.1.2.Freshwater plant and animal foodstuff

A.1.3 Potable water

A.2. Materials

A.3. Energy

A.4. Monetary values in property/jobs/NBS

REGULATING AND MAINTENANCE

B.1. Regulation of waste

B.2. Flow regulation (air, water)

B.3. Regulation of physical environment

B.3.1.Atmospheric regulation

B.3.2. Water quality (regulation of drought)

B.3.3.Pedogenesis and soil quality regulation

B.4. Regulation of biotic environment

B.4.1.Lifecycle maintenance \& habitat protection

B.4.2.Gene pool protection

CULTURAL

C.1. Symbolic

C.1.1.Aesthetic heritage

C.2. Accessibility, availability, proximity

C.3. Recreation and community activities

C.3.1.Charismatic or iconic wildlife or habitats

C.4. Information and knowledge

C.4.1.Educational-subject matter for wildlife programmes \& books etc.

C.5. Mental health

C.6. Physical health/active enjoyment/recreation

C.7. Social fulfillment/social interactions

C.8. Participatory planning and governance impacts
7 authors/ 24 indicators

6 Artmann et al. 2017; EKLIPSE,

3 2016; MAES, 2016; Pakzad et

3 al. 2016; EPA, 2012; Fischer et

1 al. 2007; Rueda, 2007

3

8

12 authors/83 indicators

10 Baro, 2016; EKLIPSE, 2016;

18 Leff, 2016; MAES, 2016;

19 Pakzad et al. 2016; Schyns et al. 2015; Barrico et al. 2012;

19

12

5

18

1

12 authors/68 indicators

Artman et al. 2017; Fischer et

7

20

10

al. 2017; Grunewald et al. 2017;

EKLIPSE, 2016; Leff, 2016; MAES, 2016; Pakzad et al. 2016; Ioja et al. 2014; EPA, 2012; Agencia d'Ecología Urbana de Barcelona, 2010; Rueda, 2007; Whitford et al. 2001

The biggest number of indicators accounted (70) are quantitative indicators and were proposed to assess regulation and maintenance services as they measure mostly variables of physical environment (e.g. carbon sequestration and storage, greenhouse emissions, run-off coefficient, urban heat island effect, wind speed, Simpson's diversity index or population index ). Cultural services category is very diverse involving indicators from multiple domains easier to estimate with qualitative data than quantitative measurements, that is why qualitative indicators predominate. Some examples are social values for urban ecosystems and 
Table 3: Repeated indicators used to assess Ecosystem Services (ES), number of times being repeated in literature $(\mathrm{T})$ and the associated references.

\begin{tabular}{|c|c|c|c|}
\hline ES & Repeated indicators & $\mathrm{T}$ & References \\
\hline A. 4 . & Increased property values & 2 & Pakzad and Osmond, 2016; EKLIPSE, 2016 \\
\hline B.2. & Run-off coefficient & 2 & Whitford et al. 2001, EKLIPSE, 2016 \\
\hline \multirow[t]{7}{*}{ B.3.1. } & Carbon storage & 7 & EKLIPSE, 2016; Pakzad and Osmond, 2016; \\
\hline & Carbon sequestration & & Baro , 2016; Whitford et al. 2001;Agencia \\
\hline & $\begin{array}{l}\text { Air quality (pollutant } \\
\text { removal) }\end{array}$ & & d'Ecología Urbana de Barcelona , 2010 \\
\hline & $\begin{array}{l}\text { Share of emissions captured/ } \\
\text { sequestered by vegetation }\end{array}$ & & \\
\hline & Temperature moderation & 3 & \\
\hline & $\begin{array}{l}\text { Value of air pollutant } \\
\text { removal/avoidance }\end{array}$ & 2 & EKLIPSE, 2016; Pakzad and Osmond, 2016 \\
\hline & $\begin{array}{l}\text { Monetary values: value of } \\
\text { air pollution reduction and } \\
\text { carbon sequestration }\end{array}$ & 2 & Pakzad and Osmond, 2016; EKLIPSE, 2016 \\
\hline B.3.2. & Water consumption & 2 & $\begin{array}{l}\text { Schyns et al. 2015; Agencia d'Ecología } \\
\text { Urbana de Barcelona , } 2010\end{array}$ \\
\hline B.4. & $\begin{array}{l}\text { Diversity, biodiversity } \\
\text { (species richness, } \\
\text { abundance) }\end{array}$ & 3 & $\begin{array}{l}\text { Barrico et al. 2012; Gregory et al. 2004; } \\
\text { Krasny et al. 2016; Agencia d'Ecología } \\
\text { Urbana de Barcelona ,2010; EKLIPSE, 2016; } \\
\text { Cohen et al. 2012; Leff, 2016; Fischer } \text { et al. } \\
\text { 2017; }\end{array}$ \\
\hline \multirow[t]{2}{*}{ B.4.1. } & Functional connectivity & 3 & $\begin{array}{l}\text { EKLIPSE, 2016;Agencia d’Ecología Urbana } \\
\text { de Barcelona , 2010; Rueda, } 2007\end{array}$ \\
\hline & $\begin{array}{l}\text { Permeability index (soil } \\
\text { biotic index) }\end{array}$ & 2 & $\begin{array}{l}\text { Agencia d'Ecología Urbana de Barcelona, } \\
\text { 2010; Rueda, } 2007\end{array}$ \\
\hline C.1.1. & $\begin{array}{l}\text { Spatial perception of urban } \\
\text { green }\end{array}$ & 2 & $\begin{array}{l}\text { Agencia d'Ecología Urbana de Barcelona, } \\
\text { 2010; EKLIPSE, } 2016\end{array}$ \\
\hline \multirow[t]{5}{*}{ C.2. } & Green-space accessibility & 3 & $\begin{array}{l}\text { Grunewald et al. 2017; EKLIPSE, 2016; } \\
\text { Rueda, } 2007\end{array}$ \\
\hline & Total area of green space & 5 & $\begin{array}{l}\text { Rueda, 2007; Whitford et al. 2001; Istat, } \\
\text { 2013; Grunewald et al. 2017; Barrico et al. } \\
2012\end{array}$ \\
\hline & $\begin{array}{l}\text { Green area/inhabitant } \\
(\mathrm{SvHab})\end{array}$ & 4 & $\begin{array}{l}\text { Agencia d'Ecología Urbana de Barcelona, } \\
\text { 2010; Grunewald et al. 2017; Istat, 2013; } \\
\text { MAES, } 2016\end{array}$ \\
\hline & $\begin{array}{l}\text { Proximity to green spaces } \\
\text { (PV) }\end{array}$ & 4 & $\begin{array}{l}\text { Agencia d'Ecología Urbana de Barcelona, } \\
\text { 2010, EKLIPSE, 2016; Rueda, 2007; Ioja et } \\
\text { al. } 2014\end{array}$ \\
\hline & Structural connectivity & 4 & $\begin{array}{l}\text { Pakzad and Osmond, 2016; Rueda, } 2007 \text {; } \\
\text { Ioja et al. 2014; Artmann et al. } 2017\end{array}$ \\
\hline C.7. & Social cohesion & 3 & $\begin{array}{l}\text { Pakzad and Osmond, 2016; EKLIPSE, 2016; } \\
\text { Artmann et al. } 2017\end{array}$ \\
\hline
\end{tabular}




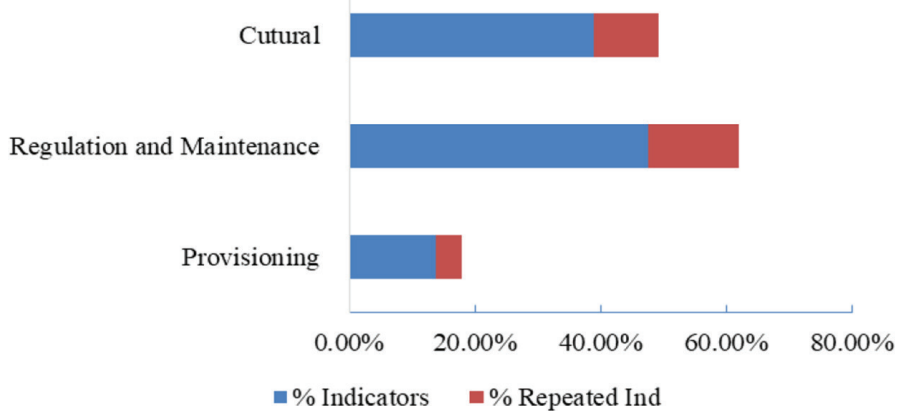

Figure 1: Percentages occupied by indicators for each theme of ES and percentage of repeated ones.

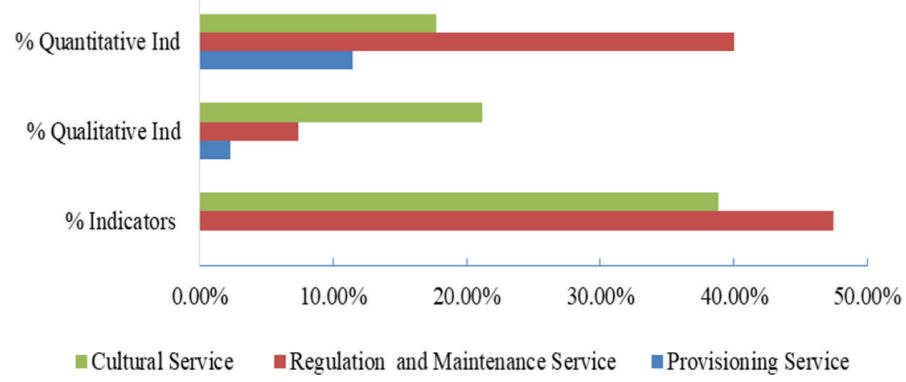

Figure 2: Percentage of qualitative/quantitative indicators associated with ES.

biodiversity [15], mental health changes, opportunities for recreation, or tourism and social interaction (community livability).

Very few works [14-16] take into account the whole range of services provided by urban green infrastructure.

Pakzad and Osmond [16] proposed an integrate method called weighted average index (WAI) based on 16 selected indicators. Agencia d'Ecologia Urbana de Barcelona [15] uses the same type of approach, involving multiple areas without reaching to build an integrated index. Through the current report [15], which we may say that is an ecosystem vision of sustainable city trends, Vitoria-Gasteiz (Spain) sustainable development goals are described and evaluated. Within the green capital, urban indicators assessed urban sustainability in order to create a desirable city model. Agencia d'Ecologia Urbana de Barcelona developed a thematic classification of 50 indicators structured in eight areas that is applied in Vitoria-Gasteiz. Vitoria-Gasteiz Sustainability Plan is representative not only for the holistic vision but also for its practically results after applying urban green indicators and establishing even minimum and desirable objectives.

Several authors [14], [16], [31] wanted to attest the potential of green infrastructure as a planning tool. They are taking into account concepts like social justice or social cohesion, looking for benefits for whole society when it comes to embrace UGI as a new planning tool.

The main purpose of most of the articles, which investigate GI indicators, is to integrate a management plan adopted by policy-makers or stakeholders. Some of the reviewed works [14], [16], [31] emphasize the potential of GI Indicators as a planning tool. In this way, 
indicators allow establishing goals, estimating the performance, synthesizing and conveying information. The main purpose of using indicators in a policy context is to provide messages to stakeholders and policy actors to achieve better governance and simplified information and communication [37].

None of the reviewed works analyze the interdependence between social, environmental and economic in an explicit way. However, these connections are inferred from the fact that some indicators could measure services of different groups (e.g. total green area, structural connectivity and distribution of green spaces). In this way, further research should explore the potential of co-benefits among different ES. Besides, further research regarding provisioning services (nutrition-marine plan and animals, materials-biotic materials, energy-renewable biofuels), regulation and maintenance services (regulation of waste-bioremediation, flow regulation-mass flow regulation, regulated of biotic environment-pest and disease control) and cultural (symbolic-spiritual) is required to develop service classes and groups indicators to fill the gaps to estimate their benefits.

Urban green infrastructure aims to bring together all three sustainable development spheres, achieve sustainability goals, ensure a healthy community preoccupied for physical, environment, biodiversity conservation and well-being of inhabitants.

\section{CONCLUSIONS}

The article reviews the most relevant urban green indicators at the urban scale. They are suitable to provide sustainability evidence, resulting also as an effective tool to assess benefits provided by urban green spaces. Green indicators are relevant to the management of green infrastructure and the assessment of its properties. In addition, indicators are a useful tool to communicate stakeholders the benefits of green spaces in urban areas.

This paper classifies urban green indicators according to existing ecosystem and landscape services frameworks.

It is necessary to use urban green indicators to establish the synergies between urban green elements. We should explore indicators that are more complex and that could be useful to interpret the ecosystem services co-benefits. In the existing literature, these interconnections are poorly described and further applied research would be necessary.

It is essential to unify indicators, to create integrated indexes and provide standards with the aid of green indicators, to help the cities to develop an effective urban planning and management tool. Cities sustainability depends on minimum desirable environmental, social and economic objectives and the holistic approach provided by integrated indexes done on proposed indicators. However, we are still far from their incorporation in applied urban planning and management.

\section{ACKNOWLEDGEMENTS}

This work was supported by the European Union's Horizon 2020 research and innovation programme under the project Green Cities For Climate and Water Resilience, Sustainable Economic Growth, Healthy Citizens and Environments with reference 730283.

\section{REFERENCES}

[1] United States Environmental Protection Agency, A Framework for Sustainability Indicators at EPA, EPA/600/R/12/687, 2012. www.epa.gov/ord (accessed online 15 May, 2018).

[2] United Nations Commission on Sustainable Development, Framing Sustainable Development. The Brundtland Report - 20 Years On, Sustainable Development in action, April 2007. www.un.org/esa/sustdev/csd/csd15/media/backgrounder_brundtland.pdf (accessed on 03 June, 2018). 
[3] United Nations, Transforming our world: the 2030 Agenda for Sustainable Development. A/RES/70/1, Seventieth session, Distr.: General, 21 October, 2015, www.sustainabledevelopment.un.org (accessed on 03 June, 2018).

[4] United Nations. New Urban Agenda. United Nations Conference on Housing and Sustainable Urban Development Conference (Habitat III), Quito, Ecuador, 17-20 October, 2017. www.habitat3.org/the-new-urban-agenda/ (accessed on 05 June, 2018).

[5] Hansen, R. \& Pauleit, S., From multifunctionality to multiple ecosystem services? A conceptual framework for multifunctionality in green infrastructure planning for urban areas. Ambio, 43, 516-529, 2014.

[6] United Nations Development Programme (UNDP). Sustainable Development Goals. www.undp.org/content/undp/en/home/sustainable-development-goals.html (accessed on 16 July, 2018).

[7] European Commission, Communication from the commission to the European Parliament The Council, The Council, The European Committee of the regions, Green Infrastructure (GI) Enhancing Europe's Natural Capital, Brussels, 2013. ww.ec.europa.eu/ environment/nature/ecosystems/docs/green_infrastructures/1_EN_ACT_part1_v5.pdf (accessed on 30 May, 2018).

[8] European Commission. Environment. Nature and Biodiversity. Nature, 2000._ec.europa. eu/environment/nature/natura2000/index_en.htm (accessed on 20 February, 2018).

[9] Valles-Planells, M., Galiana, F. \& Van Eetvelde, V., The principles of sustainability are associated to landscape management. Ecology and Society, 19(1), 44, 2014.

[10] Benedict, M.A. \& McMahon, E.T and The Conservation Fund., Green Infrastructure: Linking Landscapes and Communities, Island Press, 2012.

[11] Countryside Agency, Countryside In and Around Towns: The Green Infrastructure of Yorkshire and the Humber. CA, Leeds, 2006. www.leedsbeckett.ac.uk /as/cudem/ CIAT_final.pdf (accessed on 10 July, 2018).

[12] Haines-Young, R. \& Potschin, M., Common International Classification of Ecosystem Services (CICES) V5.1 Guidance on the Application of the Revised Structure, UK, 2017.www.seea.un.org/sites/seea.un.org/files/lg23_cices_v5.1_final_revised_guidance_03-10-2017.pdf (accessed on 14 February, 2018).

[13] European Environmental Agency. www.eea.europa.eu/ (accessed on 14 February, 2018).

[14] European Union. Horizon 2020. EKLIPSE Expert Working Group on Nature-based Solutions, An impact evaluation framework to guide the evaluation of nature-based solutions projects. (Draft) 19, 2016. www.eklipse-mechanism.eu/apps/Eklipse_data/ website/EKLIPSE_Report1-NBS_FINAL_Complete-08022017_LowRes_4Web.pdf (accessed on 10 February, 2018).

[15] Agencia d'Ecología Urbana de Barcelona, Plan de indicadores de sostenibilidad urbana de Vitoria-Gasteiz. Ayuntamiento de Vitoria-Gasteiz, 2010. www.vitoria-gasteiz.org/wb021/ http/contenidosEstaticos/adjuntos/es/89/14/38914.pdf (accessed on 10 March, 2018).

[16] Pakzad, P. \& Osmond, P., Developing a sustainability indicator set for measuring green infrastructure performance. Procedia - Social and Behavioral Sciences, 216, 68-79, 2016. doi:10.1016/j.sbspro.2015.12.009.

[17] Schyns, J.F., Hoekstra, A.Y. \& Booij, M.J., Review and classification of indicators of green water availability and scarcity. Hydrol. Earth Syst. Sci., 19, pp. 4581-4608, 2015. doi:10.5194/hess-19-4581-201.

[18] Whitford, V., Enos, A.R. \& Handley, J.F., City form and natural process-indicators for the ecological performance of urban areas and their application to Merseyside. Lanscape and Urban Planning, UK, 57, pp. 91-103, 2001. Journal ISSN: 0169-2046. 
[19] Gregory, R.D., Gibbons, D.W. \& Donald, P.F., Bird census and survey techniques. In Bird Ecology and Conservation, A Handbook of Techniques, eds. W.J. Sutherland, I. Newton, \& R.E. Green, 17-55, Oxford University Press: Oxford, 2004.

[20] Environmental Commission City of Bloomington. Bloomington Environmental Quality Indicators. Fischer, B.C., Steinhoff, M., Mincey, S. \& Dye, L., The 2007 Bloomington Street Tree Report 01-07: An Analysis of Demographics and Ecosystem Services, Indiana, 2007.

[21] Rueda, S., El urbanismo ecológico - Un nuevo urbanismo para abordar los retos de la sociedad actual. Neutra, ISSN 1138-1507, 5, 30-37, 2007.

[22] Barrico, L., Azul, M.A., Morais, M.C., Coutinho, A.P., Freitas, H. \& Castro, P., Biodiversity in urban ecosystems: Plants and macromycetes as indicators for conservation planning in the city of Coimbra. Landscape and Urban Planning, 106(1), 88-102, 2012. https://doi.org/10.1016/j.landurbplan.2012.02.011

[23] Cohen, M., Baudoin, R., Palibrk, M., Persyn, N. \& Rhein, C., Urban biodiversity and social inequalities in built-up cities: New evidences, next questions. The example of Paris, France. Landscape and Urban Planning, 106(3), 277-287, 2012. https://doi.org/10.1016/j.landurbplan.2012.03.007

[24] Krasny, M.E., Lundholm, C., Shava, S., Lee, E. \& Hiromi Kobori, H., Chapter 30 Urban Landscapes as Learning Arenas for Biodiversity and Ecosystem Services Management. Urbanization, Biodiversity and Ecosystem Services: Challenges and Opportunities, 629-644, 2013. https://doi.org/10.1007/978-94-007-7088-1_30

[25] I. Stat, Italian Statistics. Green and other environmental data.Green areas www.dati. istat.it/?lang=en (accessed on 15 May, 2018).

[26] Iojã, C.I., Grãdinaru, S.R., Onose, D.A., Vânau, G.O. \& Tudor, A.C., The potential of school green areas to improve urban green connectivity and multifunctionality. Urban Forestry \& Urban Greening, 13(4), 704-713, 2014. https://doi.org/10.1016/j. ufug.2014.07.002

[27] Baró, F., Urban Green Infrastructure: Modeling and mapping ecosystem services for sustainable planning and management in and around cities, Thesis for: Ph.D. Program in Environmental Science and Technology (Autonomous University of Barcelona UAB), 2016. doi:10.13140/RG.2.2.35758.92485/1

[28] European Union, Mapping and Assessment of Ecosystems and their Services, 3rd Report, Mapping and assessing the condition of Europe's ecosystems: Progress and challenges MAES, Mapping and Assessment of Ecosystems and their Services, 2016.

[29] Kabisch, N., Strohbach, M., Haase, D. \& Kronenberg, J., Urban green space availability in European cities. Ecological Indicators, 70 586-596, 2016. https://doi.org/10.1016/j. ecolind.2016.02.029

[30] Leff, M., The Sustainable Urban Forest a Step-by-Step Approach, Davey Institute/ USDA Forest Service USFS Philadelphia Field Station, 2016. www.itreetools.org/ resources/content/Sustainable_Urban_Forest_Guide_14Nov2016.pdf (accessed on 15 March, 2018).

[31] Artmann, M., Kohler, M., Meinela, G., Ganb, J. \& Ioan-Cristian Ioja, I.C., How smart growth and green infrastructure can mutually support each other - A conceptual framework for compact and green cities. Ecological Indicators, 2017. doi:10.1016/j. ecolind.2017.07.001

[32] Grunewald, K., Richter, B., Meinel, G., Herold H. \& Syrbe, R.-U., Proposal of indicators regarding the provision and accessibility of green spaces for assessing 
the ecosystem service "recreation in the city" in Germany. International Journal of Biodiversity Science, Ecosystem Services \& Management, 13(2), 26-39, 2017. https://doi.org/10.1080/21513732.2017.1283361

[33] Lundh, J., Indicators for ecosystem services in urban green space management, UPTEC W17 023 Examensarbete 30 hp, 2017. www.w-program.nu/filer/exjobb/Johan_Lundh. pdf (accessed on 1 June, 2018). 